the rise in steam pressure corresponding to the increased economy.

The steam-engine has held its own as a prime mover for two centuries. The gas-engine has now become a more efficient heat engine, and a powerful competitor, and electricity has become an economical transmitter of power.

Heat, electricity, and mechanical work are mutually convertible. The time may come when heat may be converted into electric current with as little loss as that involved in the conversion of electric current into mechanical work when that time comes, the heat efficiency of the prime mover will exceed that of the gas-engine in a greater degree than the gas-engine has exceeded that of the steam-engine.

\section{UNIVERSITY AND EDUCATIONAL.} INTELLIGENCE.

Cambridge.-The Public Orator, Dr. Sandys, of St. John's College, spoke as follows in presenting, for the complete degree of Master of Arts honoris causa, $\mathrm{Mr}$. Howard Marsh, recently elected professor of surgery in succession to Sir George Humphry, who died in 1896 .

Haud ita pridem, ut meministis omnes, plenus annis, plenus honoribus, e vita excessit vir insignis, per annos plurimos primum anatomiam, deinde chirurgiam, inter nosmet ipsos praeclare professus. Qui qualis quantusque vir fuerit, quanto scientiae amore, quanta animi alacritate, quanta sermonis facundia praeditus, non est quod longius exsequar: vosmet ipsi vobiscum recordamini. Chirurgiae vero professoris nostri primi in locum, annorum septem intervallo interposito, nuper electus est vir egregius, quem, tot aliis ministrum salutis, Academiae nomine hodie ipsum jubemus salvere. Viri talis autem inter laudes, non nostrum erit hodie scientiae tam reconditae penetralia perscrutari, non artis intimae mysteria occulta et abstrusa in lucem proferre; ne corporis quidem mala illa dura verbis duris

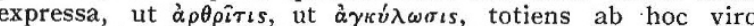
feliciter levata, coram vobis hodie commemorabuntur. Mentis potius ad bona praeclara transibimus, et professorem nobis nuper datum propterea praesertim animo laeto accipienus, quod ingenio tam vivido, judicio tam subacto est praeditus, in rebus minutissimis observandis tam subtilis, in rebus obscurissimis explicandis tam lucidus. Viro in ea parte medicinae quae manu curat insigni manus libenter tendimus, dextraeque tam sollerti dextram libenter jungimus. Duco ad vos baronetti quidem illustris, Jacobi Paget, quondam adjutorem, equitis autem insignis, Georgii Humphry, nunc demum successorem, virum nobis omnibus acceptissimum, Professorem Marsh.

A special course of advanced lectures on certain general aspects of zoology, to be given at the zoological laboratory during the Michaelmas and Lent terms, on Tuesdays and Saturdays at noon, commenced on November 17. The course includes lectures by the following:- $\mathrm{Mr}$. Brindley, regeneration; Mr. Doncaster, (I) Weismann and his work, (2) experiments with Echinoderm eggs and larvæ; $\mathrm{Mr}$. Fletcher, cell-structure, cell-division and maturation of germ-cells; Mr. J. S. Gardiner, marine fauna; Mr. Hopkins, animal pigments; Mr. Punnett, metamerism; Mr. Shipley, parasites. The first two lectures are on parasites, by Mr. Shipley. The order of the other lectures will be arranged later.

Mr. Bertram Hopkinson, son of the late Dr. John Hopkinson, F.R.S., has been elected professor of mechanism and applied mechanics in succession to Prof. Ewing. Prof. Hopkinson was placed in the first division of the first class of the mathematical tripos, part ii., in 1895 , and was proxime accessit for the Smith's prizes in 1896 .

Mr. W. Morley Fletcher, Trinity, has been appointed demonstrator of physiology.

A Clerk Maxwell studentship for research in physics will be filled up at the end of this term. Applications are to be sent to Prof. J.' J. Thomson by December I8. Candidates must have worked at least one term at the Cavendish Laboratory.

The special board for medicine proposes to establish a postgraduate examination and diploma in tropical medicine and No. I 777 , vor. 69] hygiene, intended to meet the needs of military, colonial, and missionary practitioners. Mr. Chamberlain and $\mathrm{Mr}$. Brodrick have expressed their approval of the proposal in the interest of the imperial medical services.

A syndicate consisting of Dr. Guillemard, Dr. A. Macalister, Dr. Haddon, Prof. Ridgeway, Mr. J. G. Frazer, Mr. A. E. Shipley, Mr. W. L. H. Duckworth, and Dr. Rivers, is proposed to consider the better organisation of the study of anthropology in the University.

The Advisory Board on Military Education and Training, appointed by the Secretary of State for War in April last, has stated some of the conclusions which have been arrived: at, and now carry the approval of the Secretary of State. With regard to the selection of the candidates for commissions through Sandhurst and Woolwich, it is proposed to subject them to a twofold test, consisting of a preliminary qualification and a competitive examination. The Advisory Board is of opinion that the subjects covered by the qualifying certificate (which is to be given not by a special examination, but some substitute in the shape of a "leaving certificate") must include:-(I) English; (2) history and geography; (3) mathematics (elementary); (4) French or German; (5) either (a) Latin or Greek, or (b) science. By "science" in this scheme is meant such combination of experimental or natural sciences as the Board may approve. Provided always that the sciences recognised shall have been taught in a sufficiently extended course, say three years, involving a sufficient amount of laboratory or field work. In the competitive examination the Board considers that for Woolwich candidates it should consist of three compulsory subjects, viz. English, either French or German, mathematics i., and of any two out of the following :- mathematics ii., science, history, French, German, Latin, Greek. For Sandhurst candidates they propose that there should be two compulsory subjects, viz. English, and French or German, with any two of the following :- mathematics i., mathematics ii., science, history, French, German, Greek, Latin. It consequently seems possible, and in view of public school traditions highly probable, that we may have young officers in training under the new regulations who are completely ignorant of scientific method.

SOME severe criticisms of our system of education for officers in the Army were made by Lieut.-Colonel F. N. Maude at the Royal United Service Institution last week in a lecture on "Military Education." He remarked that the rising generation of young officers as a body were leaving the public schools with less education than that of many of our rank and file. In his experience, Militia, Sandhurst, and Woolwich candidates were all willing to learn, and were easily interested in their work for a time, but as a body they were mentally incapable of " concentration" for more than a few minutes. He suggested that the Government should appoint a committee of the highest specialists in nervous diseases, loss of control, and similar troubles, and get them to report on the psychological, not the physiological, influence of " drill " exercises in restoring and developing will-power in the individual. Having secured concentration, what were they to teach? Primarily, they needed the power to observe facts. accurately-i.e. scientific teaching; next, the knowledge of facts previously registered-i.e. history; and, thirdly, the power to reason accurately from given data-i.e. mathematics. But neither history nor science could be studied without a knowledge of modern languages. History was unintelligible without physiography, geography, and topography-hence these subjects should form integral parts of its teaching. Let the Government, he said, settle a course of instruction which could only be accomplished in the time by concentration of purpose on the decisive factors, and would require in every school a thoroughly modern equipment of educational means and appliances, and, to start the system, let it send its own experts round to advise and assist headmasters. In conclusion, he strongly urged the importance of securing for the Army a good supply of older: university and Militia candidates, men who joined the service not only with a fuller sense of responsibility than one found in the average schoolboy, but also with a far wider and surer basis of knowledge. 
UNDER the joint auspices of the Technical Education Board of the London County Council and of the Geographical Association, two conferences will be held on Thursday, January 7, 1904, in the South-western Polytechnic, Manresa Road, Chelsea. In the morning, at il o'clock, Mr. H. J. Mackinder, reader in geography at Oxford, and the appointed teacher of geography in the University of London, will open a discussion on the development of geography out of hature-study. In the afternoon practical methods of teaching geography will be dealt with. Mr. Lomas, of Liverpool, will take up the question of teaching geography by excursions; Mr. T. Alford Smith, St. Dunstan's College, Catford, will describe a method of using the globe and lantern views; Mr. P. F. Kendall, of the Yorkshire College, will discuss methods of making and using models; and Mr. A. J. Herbertson, of the Oxford University School of Greography, will advocate the employment of Ordnance maps in teaching geography, and will, in particular, deal with sheets which are illustrative of typical land forms. In connection with these conferences an exhibition of geographical appliances, maps, and books of use to teachers will be arranged. It will probably be open from Tuesday, January 5, to Saturday, January 9, at the South-western Polytechnic. The Geographical Association has appointed a special committee to select exhibits.

LORD KELVIN on November 13 received the honorary degree of D.Sc. from the University of Wales. On the evening of the previous day he received the honorary membership of the South Wales Engineers' Institute, and in expressing his thanks for the honour, he remarked that engineers all over the world had still a good deal to learn as to the real value of university training. In the matter of the education of foremen in engineering works the Germans had learned how to give them scientific knowledge in a way in which we in England had not given it. It was necessary for the young engineer to learn the practical as well as the theoretical, and this could only be accomplished satisfactorily by the student's spending half his year at the university and half in the workshop, where he might learn to apply the scientific knowledge which he had acquired in the university.

At the Sir John Cass Technical Institute, Aldgate, on Tuesday, November i 7 , the prizes and certificates gained by students during the past session were distributed by Sir Henry Roscoe. The institute is one of the polytechnics aided by the Technical Education Board of the London County Council and by the City Parochial Foundation. In addition to general instruction in the experimental sciences, art, commercial subjects, and domestic economy, special attention is given to the study of metals both from the scientific and the artistic side. Sir Henry Roscoe, in addressing the students, said that he hoped all present would agree with him that enough had been said about the value of the application of the principles of science and of art to industry, and that the time for work had come. Over and above the ordinary courses of instruction it is of the utmost importance that the higher work of students, especially research work, should be encouraged. What original work teaches is-how to overcome difficulties, how to obtain a mastery over opposing forces, how, in fact, successfully to tackle new problems when they present themselves, as they are ever doing to those who have eyes to see. Without this capability a man can only run in the beaten track, with it he has a weapon in his hand which gives him power to strike out new paths and to open up fresh and fertile ground. As in the scientific sphere, so also in the domain of art-the same guiding spirit holds the fort. Taste needs refinement, hand and eye require training, the craftsman, like the man of science, must be imbued with the spirit of progress as well as with a love of his art. Referring to the relation between the London University and polytechnics as regards internal students, Sir Henry Roscoe remarked that instruction given in the polytechnics must be of a real university type. It would be fatal to the prestige of the university were its necessarily high standard of efficiency lowered to meet the exigencies of the case. The course of study must be an extended one, as the hours devoted to work in the evening are necessarily shorter than those in the day; but the total time spent in study must be the same for both day and evening. students, though a substantial reduction in time has been granted to those regularly employed during the day.

\section{SOCIETIES AND ACADEMIES \\ LONDON.}

Royal Society. - "The Vapour Pressure of Liquid Oxygen un the Scale of the Constant-volume Oxygen Thermometer filled at different Initial Pressures." by Dr. Morris W. Travers and Dr. Charles J. Fox. Communicated by Sir William Ramsay, K.C.B., F.R.S. Received June 26.

The vapour pressures of liquid oxygen and of liquid hydrogen on the scales of the constant-volume hydrogen and helium thermometers have recently been determined by one of us in conjunction with Dr. A. Jaquerod and Mr. G. Senter, and it has been found that two scales of temperalure differ by amounts which increase as the temperature falls (Phil. Trans., A., vol. cc.).

$\begin{array}{llccc}\text { Liquid oxygen ... } & \ldots & \begin{array}{c}\text { Vapour } \\ \text { pressure }\end{array} & \begin{array}{c}\text { Hydrogen } \\ \text { scale }\end{array} & \begin{array}{c}\text { Helium } \\ \text { scale }\end{array} \\ \text { Liquid hydrogen } & . . & 760 & 90^{\circ} \cdot 10 & 90^{\circ} 20 \\ \text { Liquid } & 20 \cdot 22 & 20 \cdot 41\end{array}$

These results are in accordance with Callendar's calculations of the deviation from the thermodynamic scale of measurements with thermometers filled at an initial pressure of $1000 \mathrm{~mm}$. of mercury at the melting point : of ice. Whether the deviation becomes smaller when the thermometers are filled at a lower pressure has not been determined, and, indeed, with the means at our disposal it would be practically impossible to do so. In order, therefore, to investigate the variation of the readings of the gas thermometer with change of initial pressure, we decided to measure th: vapour pressures of liquid oxygen on the scales of the constant-volume oxygen and nitrogen thermometers, for which the deviations from the thermodynamic scale are cclisideraibly greater.

Makower and Noble, using the method of Travers and Jaquerod, have found that the pressure coefficient of oxygen at an initial pressure $\mathrm{Po}$ may be expressed by the formula

$$
\alpha=0.0036642+0.00000001457 \text { Po, }
$$

where $\mathrm{Po}$ is expressed in millimetres. Values derived from this expression were employed in calculating the temperatures corresponding to the vapour pressure of liquid oxygen on the scale of the oxygen thermometer filled at different initial pressures.

The results are stated in the following table :-

\begin{tabular}{|c|c|c|c|c|}
\hline \multicolumn{2}{|c|}{$\begin{array}{l}\text { Gas in } \\
\text { thermometer }\end{array}$} & $\begin{array}{l}\text { Pressure on gas in } \\
\text { thermometer at } \\
\text { ice point }\end{array}$ & $\begin{array}{l}\text { Pressure } \\
\text { coefficient }\end{array}$ & $\begin{array}{l}\text { Boiling point o } \\
\text { liquid oxygen }\end{array}$ \\
\hline Helium & $\cdots$ & $\ldots \quad 1000 \mathrm{~mm}$ & 0.00366255 & $90: 20$ \\
\hline Oxygen & $\ldots$ & $\ldots \quad 1000$ & 0.0036788 & $88 \cdot 7^{1}$ \\
\hline & & $73 \mathrm{I}$ & 0.0036748 & 89.02 \\
\hline & & $65^{8}$ & 0.0036738 & 89.09 \\
\hline & & 484 & 00036713 & 89.31 \\
\hline & & 336 & 0.0036692 & $89 \cdot 48$ \\
\hline & & o & 0.0036642 & $99.8^{1}$ \\
\hline
\end{tabular}

The results show that for very low pressures in the thermometer the oxygen scale converges towards the helium scale. The fact that the deviation does not appear to vanish at low pressures may be due to a tendency on the part of the gaseous molecules to associate at higher pressures.

Mathematical Society, November I2.--Prof. H. Lamb, president, in the chair.-The council and officers for the ensuing session were elected. They are as follows :- president, Prof. Lamb; vice-presidents, Prof. Elliott, Dr. Hobson, Dr. Baker; treasurer, Prof. Larmor; secretaries, Prof. Love and Prof. Burnside; other members of council, Mr. Campbell, Br. Glaisher, Mr. Grace, Mr. Macdonald, Major MacMahon, Mr. Mathews, Mr. Western, Mr. Whittaker, Mr. A. Young.-The following papers were communicated:-Prof. J. D. Everett, Note on Borgnet's method of dividing an angle in an arbitrary ratio. The method, which depends on the construction of a certain transcendental curve, was given by Borgnet in Rouen. Acad. 